OPEN ACCESS

Edited by:

Scott D. Gray-Owen, University of Toronto, Canada

Reviewed by:

Sukanya Narasimhan, Yale University, United States Gary Jarvis,

University of California San Francisco, United States

*Correspondence: Peter A. Rice peter.rice@umassmed.edu

Specialty section:

This article was submitted to Microbial Immunology,

a section of the journal

Frontiers in Immunology

Received: 01 September 2018 Accepted: 07 February 2019 Published: 27 February 2019

Citation:

Gulati S, Shaughnessy J, Ram S and Rice PA (2019) Targeting Lipooligosaccharide (LOS) for a Gonococcal Vaccine. Front. Immunol. 10:321. doi: 10.3389/fimmu.2019.00321

\section{Targeting Lipooligosaccharide (LOS) for a Gonococcal Vaccine}

\author{
Sunita Gulati, Jutamas Shaughnessy, Sanjay Ram and Peter A. Rice* \\ Division of Infectious Diseases and Immunology, Department of Medicine, University of Massachusetts Medical School, \\ Worcester, MA, United States
}

The increasing incidence of gonorrhea worldwide and the global spread of multidrug-resistant strains of Neisseria gonorrhoeae, constitute a public health emergency. With dwindling antibiotic treatment options, there is an urgent need to develop safe and effective vaccines. Gonococcal lipooligosaccharides (LOSs) are potential vaccine candidates because they are densely represented on the bacterial surface and are readily accessible as targets of adaptive immunity. Less well-understood is whether LOSs evoke protective immune responses. Although gonococcal LOS-derived oligosaccharides (OSs) are major immune targets, often they undergo phase variation, a feature that seemingly makes LOS less desirable as a vaccine candidate. However, the identification of a gonococcal LOS-derived OS epitope, called $2 \mathrm{C} 7$, that is: (i) a broadly expressed gonococcal antigenic target in human infection; (ii) a virulence determinant, that is maintained by the gonococcus and (iii) a critical requirement for gonococcal colonization in the experimental setting, circumvents its limitation as a potential vaccine candidate imposed by phase variation. Difficulties in purifying structurally intact OSs from LOSs led to "conversion" of the 2C7 epitope into a peptide mimic that elicited cross-reactive IgG anti-OS antibodies that also possess complement-dependent bactericidal activity against gonococci. Mice immunized with the $2 \mathrm{C} 7$ peptide mimic clear vaginal colonization more rapidly and reduce gonococcal burdens. $2 \mathrm{C} 7$ vaccine satisfies criteria that are desirable in a gonococcal vaccine candidate: broad representation of the antigenic target, service as a virulence determinant that is also critical for organism survival in vivo and elicitation of broadly cross-reactive IgG bactericidal antibodies when used as an immunogen.

Keywords: N. gonorrhoeae, Lipooligosaccharide, vaccine, peptide mimic, complement

\section{INTRODUCTION}

Gonococcal vaccine development is challenging because the correlates of immune protection are not fully known (1); mechanisms of protective immunity against gonococcal infection in humans are also unknown. Potential mechanisms focus on: (1) antibody ( $\mathrm{Ab}$ ) binding to Neisseria gonorrhoeae ( $\mathrm{Ng}$ ) together with complement activation that results in direct killing (bactericidal activity) of the organism (2, 3); (2) Ab binding and complement activation to enable opsonophagocytic killing (2); (3) Ab binding to prevent adhesion or invasion (4) and (4) $\mathrm{T}$ cell help. Beneficial $\mathrm{T}_{\mathrm{H}} 1$ responses predominate in several successful vaccine approaches that use a female mouse model of gonococcal infection (5-7). 
Gonococcal surface molecules that may be appropriate vaccine targets often are antigenically variable and modify epitopes by antigenic or phase variation (8), which complicates vaccine development by creating an ever-changing bacterial surface. The ability to modify surface determinants is beneficial for gonococci and results in evasion strategies to increase fitness and facilitate adaptation of organisms to their environment. Unfortunately, in human infection, adaptive immune responses directed against conserved antigens fail to elicit protection against future bouts of infection; in fact, repeat infections are common, not only because of re-exposure to unidentified infected partners (9) but also because robust protective immune responses are not elicited. Immune responses that do occur may contain subversive elements that enhance the risk for future infection $(10,11)$. In female mice, experimental gonococcal infection can suppress the development of adaptive immune responses by inducing regulatory cytokines TGF- $\beta$ and IL-10 and type 1 regulatory $\mathrm{T}$ (Treg) cells (12). Intravaginal treatment of infected mice with IL-12 induces persistent immunity against gonococcal reinfection, which is dependent on the production of IFN- $\gamma$ and antibodies (13) that results in an enhanced $\mathrm{T}_{\mathrm{H}} 1$ response, accelerates clearance of infection and elicits a memory response that results in protection (14).

A number of gonococcal surface components that elicit bactericidal antibodies are under examination as vaccine candidates [reviewed and tabulated (15)]. Immunization with gonococcal outer membrane elicits diverse vaginal and serum antibodies, which can be bactericidal and accelerate clearance of experimental infection (16); however, this approach is not always reproducible (5). An alternative successful approach that favored a $\mathrm{T}_{\mathrm{H}} 1$ response, employed mice immunized (primed) with PorB (the gonococcal major outer membrane protein)-expressing Venezuelan equine encephalitis (VEE) virus replicon particles (VRPs), followed by boosting with recombinant Por B (rrPorB) $(5,17)$. However, elicited antibodies were non-bactericidal.

Several promising vaccine candidates do not elicit bactericidal antibody activity in natural infection but were predicted to be potential vaccine candidates because a more robust immune response may be forced by vaccination that does not occur in natural infection. In addition, bactericidal antibody responses to several antigens may target important physiologic functions that, if disrupted, could compromise $N$. gonorrhoeae further, including colonization and invasion $(4,18-27)$, nutrient acquisition (28$35)$, and immune evasion (36-42). Vaccine candidates that elicit bactericidal antibodies have also been identified by proteomic analysis of N. gonorrhoeae surface proteins (43) and, for example, by bioinformatic analysis, in N. gonorrhoeae, of an adhesin complex protein (ACP) homolog, originally identified in $N$. meningitidis (4). Other vaccine candidates that target function but are not known to elicit bactericidal activity are also discussed in two reviews $(44,45)$. A recent study surrounding the epidemic of group B N. meningitidis infection in New Zealand calculated cross-protective efficacy of $31 \%$ against gonorrhea in persons, aged 15-30, who were administered a Group B meningococcal outer membrane vesicle (OMV) vaccine (46), which subsequently has formed the basis of a licensed Group $\mathrm{B}$ meningococcal vaccine. Human vaccination with the licensed vaccine elicits antibodies against $N$. gonorrhoeae (47) but they are non-bactericidal (48).

A successful vaccine candidate(s) may exhibit: i) a broadly representative antigenic target(s); ii) a virulence determinant(s) (for example a determinant(s) that facilitates host evasion) that can be neutralized and iii) a determinant(s) that is critical for gonococcal survival. Such a "triple threat" candidate may prove to be a useful strategy to "corner" a skillful organism that employs numerous mechanisms to escape selective pressure. Successful single antigens used as vaccines against bacteria are the capsular polysaccharides (49-52). While these are not present in $N$. gonorrhoeae, saccharide determinants are present in gonococcal lipooligosaccharides (LOSs).

\section{LIPOOLIGOSACCHARIDE (LOS) STRUCTURE}

Gonococcal LOSs consist of three oligosaccharide (OS) chains, attached to a lipid A core. The OS chains branch from two heptose residues attached to lipid A via two 2-keto-3deoxy-mannooctulosonic acid (KDO) molecules. One OS chain elongates from the first heptose (Hep I); the 2nd and 3rd chains are connected to the second heptose (Hep II) (Figure 1). The number of branches and the length of OSs in each branch vary among gonococcal strains and, indeed, in the same strain during growth in vitro and in vivo. The $\mathrm{rfaC}$ gene that encodes heptosyl transferase is required for the addition of Hep I to KDO (53) ( $r f a$ genes encoding heptosyl transferases are blocked in yellow in Figure 1).

The $r f a F$ gene product, also a (different) heptosyl transferase, adds Hep II to Hep I and is required for elongation (schematically depicted as outward in Figure 1) of the Hep I chain (54, 55). The synthesis of OS chains is modulated by a series of LOS glycosyl transferases (products of $\operatorname{lgt}$ genes). $\operatorname{lgt} F$, $\operatorname{lgt} E$, $\lg t A, \lg t B$, and $\operatorname{lgt} D$ genes are required for stepwise addition of each hexose [or hexosamine in the case of $\operatorname{lgt} A$ and $\operatorname{lgt} D$ (shown in Figure 1)] to extend the Hep I chain (Figure 1) $(56,57)$. In place of full extension, the lgtC gene encodes $\alpha$ galactosyl transferase that terminates Hep 1 with galactose $(\mathrm{Gal})$, that can undergo sialylation (shown as Neu5Ac in the orange boxes in Figure 1), creating a shorter chain (Gal $\alpha 1-4 \mathrm{Gal} \beta 1$ $4 \mathrm{Glc} \beta 1-4-$ ) attached to -Hep I (also called the $\mathrm{P}^{K}$-like LOS) (58). Expression of distinct LOS structures on the gonococcal surface is controlled by the phase variable expression of the LOS glycosyltransferases genes $\operatorname{lgt} G, \operatorname{lgt} A, \operatorname{lgt} C$, and $\operatorname{lgt} D(54,59)$ (indicated in red in Figure 1). These genes $(\operatorname{lgt} A, \operatorname{lgt} C$, and $\lg t D$ ) contain homopolymeric tracts of guanine poly $(G)$, and in the $\operatorname{lgtG}$ gene, a cytosine poly (C) tract $(56,59-62)$. Slipped strand mispairing during DNA replication can result in alteration in coding sequences, which leads to premature termination of the corresponding genes and loss of function of the encoded glycosyl transferase proteins resulting in truncated LOS structures. Phase variation of LOS results in changes in size of the predominant LOS structures that are expressed both in vitro and in vivo. LOS undergoes phase variation at a frequency of $10^{-2}-10^{-3}$ when gonococci are grown in culture $(63,64)$. Identification of 


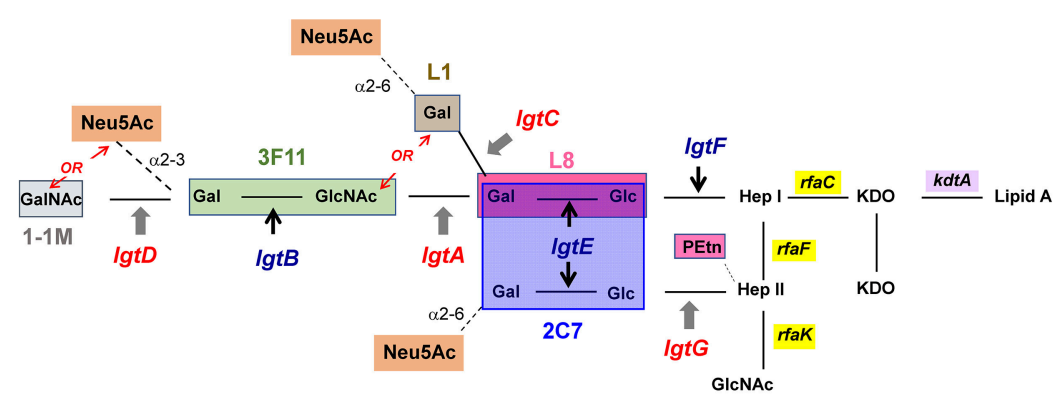

Minimal structure for mAb 2C7 binding; Hepl extensions beyond

lactose may permit binding

lactose may permit binding.
mAb L8 epitope (requires 3-phosphoethenolamine on Hepll. Hepll

glycan extension abrogates binding).

mAb 3 F11 epitope; extensions (GalNAc or Neu5Ac) abrogates binding.

mAb L1 epitope

mAb 1-1 M epitope

FIGURE 1 | General structure of gonococcal lipooligosaccharide (LOS). Gonococcal LOS consists of three oligosaccharide (OS) chains. The OS chains branch from two heptose residues attached to lipid A via two 2-keto-3-deoxy-mannooctulosonic acid (KDO) molecules. One OS chain elongates from the first heptose (Hep I)

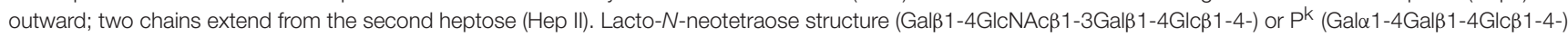
extend outward from Hep I. Phase variable genes involved in LOS biosynthesis (IgtA, C, D, and G) are shown in red; non-variable genes (IgtF, IgtE, and B) in blue. Neu5Ac (sialic acid) is shown in the orange boxes. Sialylation of LOS occurs via $\alpha 2-6$ or $\alpha 2-3$ linkage to galactose (Gal) residues. LOS branching is terminated ("capped") either by Neu5Ac (sialic acid) or otherwise extend(s) outward by adding hexose(s). LOS epitopes are defined by mAbs 2C7, L8, 3F11, L1, and 1-1M.

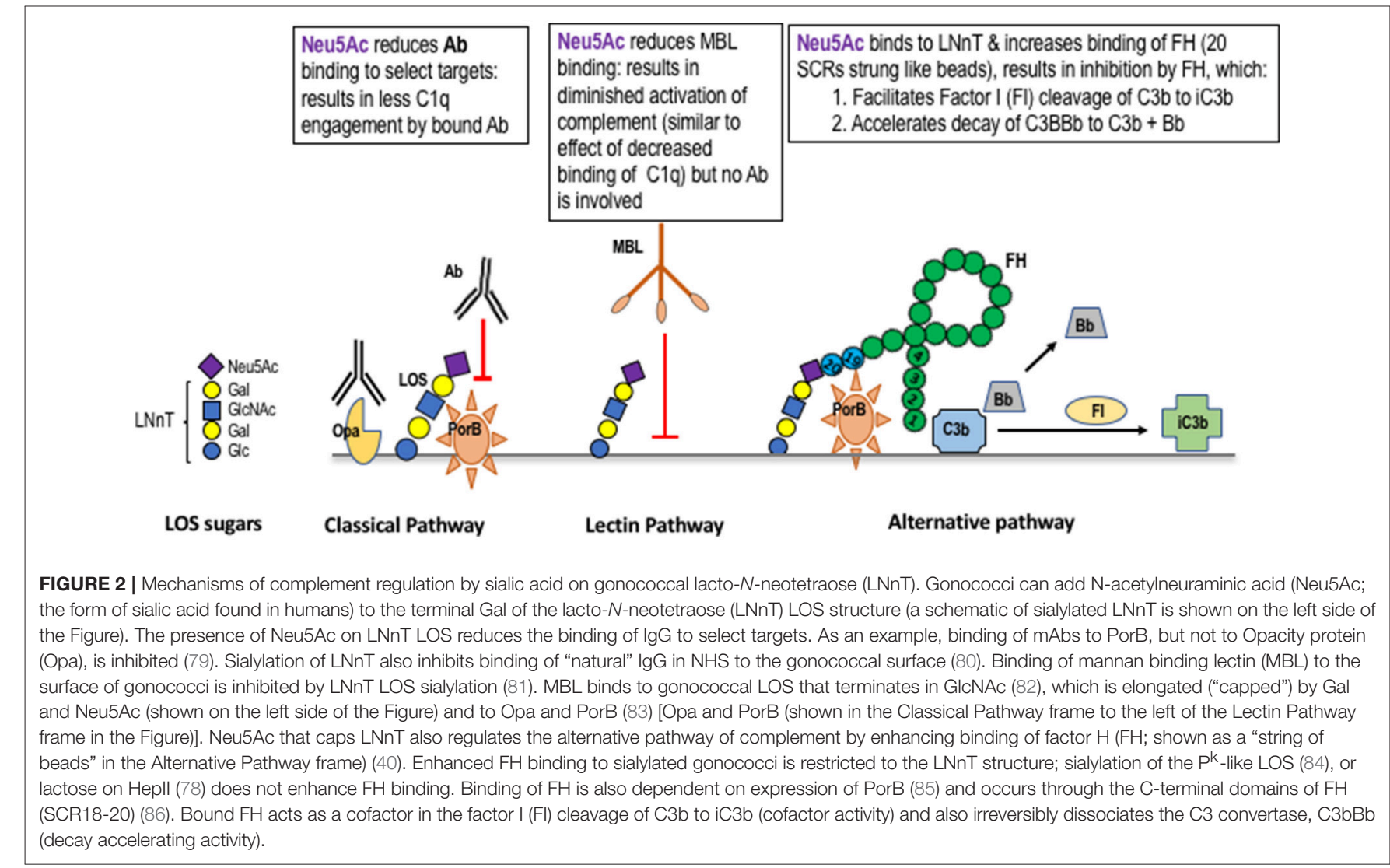


several of these individual structures on the surface of $\mathrm{Ng}$ can be demonstrated by reactivity with LOS-specific mouse monoclonal antibodies (mAbs) (depicted by colored boxes in Figure $\mathbf{1}$ and in the legend). Several of the antigenic determinants share structure with human glycosphingolipids (GSLs) (58, 65, 66). The lacto- $N$-neotetraose structure (four sugars extending from -Hep I: [Gal $\beta 1-4$ GlclNAcb1-3Gal $\beta 1-4 G l c \beta 1-4-])$ recognized by $\mathrm{mAb} 3 \mathrm{~F} 11$, is identical to human erythrocyte GSLs (6769). The alternative Hep I structure, digalactoside (Gal $\alpha 1$ $4 \mathrm{Gal} \beta 1-4 \mathrm{Glc} \beta 1-4-$, the $\mathrm{P}^{\mathrm{K}}$ structure or the L1 meningococcal serotype (Figure 1), is recognized by $\mathrm{mAb} \mathrm{L1}$ and is similar in structure to human paraglobosides (58). The fully extended Hep I, a pentasaccharide (GalNAc $\beta 1-3 \mathrm{Gal} \beta 1-4 \mathrm{GlclNAc} \beta 1-3 \mathrm{Gal} \beta 1$ $4 \mathrm{Glc} \beta 1-4-)$, defined by mAb 1-1-M (70, 71), has a structure identical to human asialo-G3 ganglioside (Figure 1) (69). This mimicry may enable $\mathrm{Ng}$ to avoid immune recognition; antigenic determinants that share structure with human GSLs, therefore, may not be suitable to elicit a response that is specific for the organism, nor would a response to shared human antigens be desirable.

Nevertheless, $\mathrm{Ng}$ LOSs possess two epitopes, which do not cross react with human GSL antigens. The first comprises Gal $\beta 1-4 G l c$ (lactose), the first two hexoses that are $\beta$-linked to Hep I (72-74). Together with a phosphoethanolamine (PEtn) substitution at the 3- (cyclic) position on Hep II (as occurs when $\operatorname{lgt} G$ is OFF and Hep II is not substituted at the 3position with glucose [Glc]), this structure is recognized by $\mathrm{mAb}$ L8 (75). The second epitope is a composite of the first epitope (L8) plus a Gal $\beta 1-4 \mathrm{Glc}$ (also lactose) that is $\alpha$-linked to Hep II (area shaded in blue in Figure 1) and represents the minimal structure $[N$-linked fatty acids in lipid A are required for maximal expression (66)] of the epitope recognized by $\mathrm{mAb} 2 \mathrm{C7}(66,76)$, called the $2 \mathrm{C} 7$ epitope. Absence of Hep II linked lactose (and therefore the complete 2C7 structure/epitope) severely attenuates gonococcal infection in the mouse cervico/vaginal colonization model $(7,77,78)$. 2C7 expression therefore, may be an important virulence factor that enhances or may be required for survival and productive infection in humans. Despite phase variation of the $\lg t G$ gene, that initiates production of the $2 \mathrm{C} 7$ epitope (expression is completed by $\operatorname{lgtE}$, which is constitutively expressed and adds Gal to Hep II linked Glc) the epitope is widely shared and expressed by most gonococci including 95\% of minimally passaged $\mathrm{Ng}$ clinical isolates (Boston) (2) and in $100 \%$ of isolates in Nanjing, China (78). In Nanjing, female subjects who were exposed and infected with $\mathrm{Ng}$ developed significantly higher levels of 2C7 Ab compared with control women who possessed minimal or no measurable $2 \mathrm{C} 7 \mathrm{Ab}$. Furthermore, as expected, there was no difference in 3F11 (a self-antigen) antibody levels in infected women vs. controls; neither were there differences in L8 antibody levels between the two groups, all of whom possessed either minimal or no measurable antibody to $3 \mathrm{~F} 11$ and L8 epitopes. The 2C7 epitope, therefore, is immunogenic in natural infection, more so than at least two other LOS structures that have been antigenically defined.

\section{LOS SIALYLATION AND COMPLEMENT RESISTANCE}

Gonococci "cap" LOS molecules in which Hep I terminates with the lacto- $N$-neotetraose structure (four sugars extending outward from Hep I [the LNnT structure]; Figure 1). Sialylation can occur using the organism's own endogenous sialyltransferase and appropriate sialic acid substrate(s) present in the mammalian genital tract. In vitro (exogenous) cytidine monophospho$\mathrm{N}$-acetylneuraminic acid (CMP-Neu5Ac) serves as a suitable substrate. Sialylated gonococci are endowed with several means to enhance pathogenicity. Sialylation of gonococcal LOS inhibits all three pathways of complement through several independent mechanisms: the classical pathway is inhibited by reducing antibody binding and possibly by reducing $\mathrm{Clq}$ (the first component of complement) engagement by bound antibody; the lectin pathway is inhibited by reducing mannose binding lectin (MBL) binding; the alternative pathway is inhibited by increased binding of $\mathrm{FH}$, a major soluble down-regulator in the alternative pathway (Figure 2). Sialylation of gonococcal LOS also decreases opsonic killing of gonococci (87-89) in part, because of decreased complement activation and C3 fragment deposition on the surface of sialylated bacteria (38, 40). Sialylation of gonococcal LOS markedly reduces opacityassociated protein (Opa)-mediated invasion of $N$. gonorrhoeae into human epithelial cell lines (90-92). Finally, sialylation of LNnT LOS occurs in organisms present in infected male urethral secretions [by electron microscopy (93)]. The importance of LNnT sialylation for virulence in humans was demonstrated in the experimental model of human infection that used a variant strain of $N$. gonorrhoeae that in vitro expressed predominantly Hep I linked lactose (Gal $\beta 1-4 \mathrm{Glc}$; L8) but upon recovery from active infection, the sialylatable LNnT species predominated (65, 94). The terminal Gal of the $\mathrm{P}^{K}$-like structure from Hep I can also be sialylated (84) and recently, Hep II lactose has been shown to accept sialic acid (Figure 1) (78), which also inhibits complement deposition and engages Siglec (sialic acid-binding immunoglobulin-type lectin) receptors to down-regulate the host inflammatory response, thereby facilitating host immune evasion (95). Sialylation of the Hep II-attached lactose component of the 2C7 structure/epitope and sialylation (78) may contribute to gonococcal virulence provided by sialylation. Of note, $\mathrm{mAb}$ 2C7 continues to bind to $\mathrm{Ng}$ LOS even when the Hep I chain is extended beyond the minimal lactose structure (66), including binding to sialylated LNnT but less so when the $\mathrm{P}^{K}$ structure/epitope is expressed (96). Glycan extensions beyond lactose on Hep II, for example with GalNAc-Gal seen in a mutant strain selected under pyocin pressure called JW31R, abrogated mAb 2C7 binding (66). However, sialylation of Hep II lactose (78) variably affects binding of $\mathrm{mAb} 2 \mathrm{C} 7$ to gonococcal strains (78). Gonococcal strains that express the $\mathrm{P}^{K}$ structure/epitope are rare/absent in vivo $(80,97)$. Hep II extension beyond lactose, to our knowledge, has not been identified in strains isolated from humans, however, the recently identified additional acceptor site for sialic acid on Hep II lactose (78), suggests that strains bearing sialic acid at this site are likely to be present in vivo. 

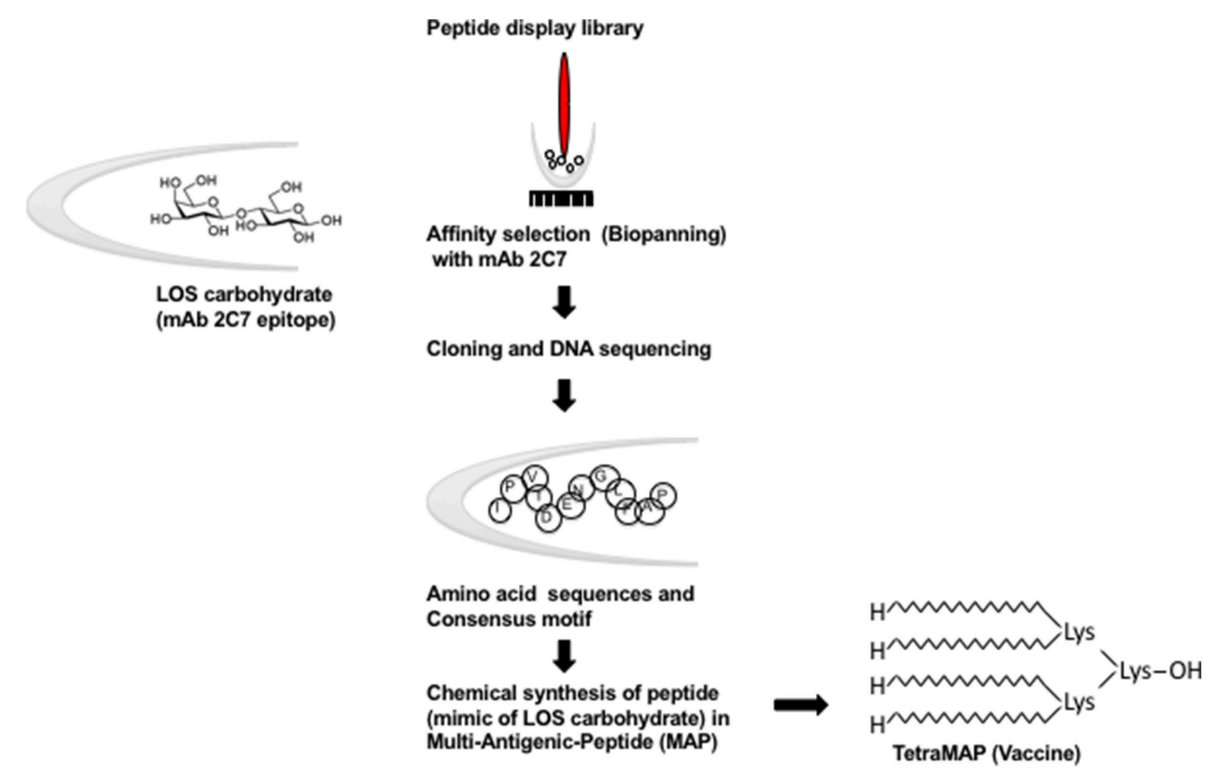

FIGURE 3 | Schematic representation of the conversion of carbohydrate (OS) epitopes into peptide mimotopes. Peptide mimics of the 2C7 epitope were identified using a random FliTrx (Flagellin-Thioredoxin) peptide display library that were screened (Biopanned) using mAb 2C7 (98). The peptide-containing clones that bound to mAb 2C7 were eluted and sequenced. An optimal peptide that contained the consensus motif was synthesized as an octameric peptide (shown here as a multiantigenic peptide [MAP]) on a lysine backbone (TetraMAP), which is the currently used configuration.

\section{THE 2C7 EPITOPE AND ITS PEPTIDE MIMIC}

The 2C7 OS epitope has been examined as a potential gonococcal candidate. Carbohydrate (OS) immunogens, themselves, evoke thymus-independent (TI) responses; they stimulate the production of low affinity IgM antibodies predominantly and there is no affinity maturation. Purification of OS from LOS may result in a change in configuration and thereby modify immunogenicity. Because the precise configurations of OS structures within intact LOSs are not known, synthesis would be difficult and optimizing the production of the correct isomers may not be possible without advance structural knowledge. The conversion of carbohydrate (OS) epitopes into peptide mimotopes having similar configuration (defined by recognition of the appropriate $\mathrm{mAb}$, e.g., $\mathrm{mAb} 2 \mathrm{C} 7$ in the case of $N$. gonorrhoeae) is a means to overcome the TI nature of carbohydrate antigens (Figure 3). Peptide mimics of the 2C7 epitope were identified using a peptide display library that was screened using mAb 2C7 [a monoclonal $\mathrm{Ab}$ with complement-dependent bactericidal and opsonophagocytic activities (2)] and identified peptide mimics were downselected immunochemically and for immunogenicity (98). Carbohydrates may contain multiple identical antigenic epitopes that provides a molecular configuration allowing carbohydrate to cross-link antigen to their cognate receptors on B cells. To emulate such configurations, an optimal peptide mimotope was chosen and a multiple antigen peptide (MAP) synthesized (Figure 3). Immunization of mice with peptide vaccine elicited cross-reactive anti-LOS antibodies that possessed dose responsive direct complement dependent bactericidal activity against gonococci (98). More recent refinements of the peptide building block have been directed: at stabilization to ensure homogeneity; optimization of synthesis to produce high yields and pairing of peptide vaccine with adjuvants that have been approved and used for human vaccination. Further characterization of vaccine induced immune responses evoked by the 2C7 peptide were enlisted to correlate efficacy of active vaccination with MAP in mice followed by experimental vaginal challenge with $\mathrm{Ng}$. Mice immunized with MAP combined with monophosphoryl lipid A (MPL), a toll-like receptor 4 (TLR4) agonist, elicited a predominant complement-activating IgG subclass (IgG2a) response resulting from $\mathrm{T}_{\mathrm{H}} 1$-biased immune stimulation (7), similar to other vaccine strategies that have proved efficacious in the experimental murine model of $\mathrm{Ng}$ vaginal/cervical colonization $(3,5)$. Clearance of $\mathrm{Ng}$ infection was hastened in vaccinated mice and reduction of bacterial burdens occurred throughout the period of colonization (7). The level of vaccine induced 2C7 immune antibodies in the vaginas of mice correlated directly with reduction in bacterial burden (80). Results of active immunization with the peptide mimic were paralleled by similar results obtained with passive immunization of mAb 2C7 (7). These results strongly support a vaccine antibody-mediated effect that was dependent on the presence of local IgG antibody in mouse vaginas (80). 2C7 vaccine satisfies the three criteria proposed above for a gonococcal vaccine: (i) similar antigenic target representation across strains; (ii) a representative virulence determinant and (iii) a critical determinant for organism survival in vivo. 


\section{CONCLUSION}

Evidence that gonococcal vaccination can succeed in humans is encouraging. Although field trials with whole cell and pilus vaccines have been unsuccessful $(99,100)$, this occurred, in part, because of exposure of vaccine recipients to heterologous strains in the wild, different than were used to prepare vaccines. Homologous protection in human experimental infection was also shown to be possible in men with favorable antibody ratios directed against the strain used in experimental infection suggesting that protective immunity against broadly cross-reactive antigens will be necessary (15) while avoiding subversive effects that might otherwise undermine protective immune responses (101). Adaptation of such an antigen(s) could result in a successful vaccine. Recent epidemiologic evidence indicates that crossreactivity between $N$. meningitidis and $N$. gonorrhoeae antigens induces a measurable level of cross protection (46), fulfilling,

\section{REFERENCES}

1. Russell MW, Hedges SR, Wu HY, Hook EWIII, Mestecky J. Mucosal immunity in the genital tract: prospects for vaccines against sexually transmitted diseases-a review. Am J Reprod Immunol. (1999) 42:58-63. doi: 10.1111/j.1600-0897.1999.tb00466.x

2. Gulati S, McQuillen DP, Mandrell RE, Jani DB, Rice PA. Immunogenicity of Neisseria gonorrhoeae lipooligosaccharide epitope 2C7, widely expressed in vivo with no immunochemical similarity to human glycosphingolipids. $J$ Infect Dis. (1996) 174:1223-37. doi: 10.1093/infdis/174.6.1223

3. Liu Y, Hammer LA, Liu W, Hobbs MM, Zielke RA, Sikora AE, et al. Experimental vaccine induces Th1-driven immune responses and resistance to Neisseria gonorrhoeae infection in a murine model. Mucosal Immunol. (2017) 10:1594-608. doi: 10.1038/mi.2017.11

4. Almonacid-Mendoza HL, Humbert MV, Dijokaite A, Cleary DW, Soo $\mathrm{Y}$, Hung $\mathrm{MC}$, et al. Structure of the recombinant Neisseria gonorrhoeae adhesin complex protein ( $\mathrm{rNg}-\mathrm{ACP}$ ) and generation of murine antibodies with bactericidal activity against gonococci. mSphere. (2018) 3:e00331-18. doi: $10.1128 / \mathrm{mSphere} .00331-18$

5. Zhu W, Chen CJ, Thomas CE, Anderson JE, Jerse AE, Sparling PF. Vaccines for gonorrhea: can we rise to the challenge? Front Microbiol. (2011) 2:124. doi: $10.3389 /$ fmicb. 2011.00124

6. Liu Y, Islam EA, Jarvis GA, Gray-Owen SD, Russell MW. Neisseria gonorrhoeae selectively suppresses the development of Th1 and Th2 cells, and enhances Th17 cell responses, through TGF-beta-dependent mechanisms. Mucosal Immunol. (2012) 5:320-31. doi: 10.1038/ mi.2012.12

7. Gulati S, Zheng B, Reed GW, Su X, Cox AD, St Michael F, et al. Immunization against a saccharide epitope accelerates clearance of experimental gonococcal infection. PLoS Pathog. (2013) 9:e1003559. doi: 10.1371/journal.ppat.1003559

8. Rotman E, Seifert HS. The genetics of Neisseria species. Annu Rev Genet. (2014) 48:405-31. doi: 10.1146/annurev-genet-120213-092007

9. LeFevre ML, Force USPST. Screening for Chlamydia and gonorrhea: U.S. Preventive Services Task Force recommendation statement. Ann Intern Med. (2014) 161:902-10. doi: 10.7326/M14-1981

10. Rice PA, Vayo HE, Tam MR, Blake MS. Immunoglobulin G antibodies directed against protein III block killing of serum-resistant Neisseria gonorrhoeae by immune serum. J Exp Med. (1986) 164:1735-48. doi: $10.1084 /$ jem.164.5.1735

11. Plummer FA, Chubb H, Simonsen JN, Bosire M, Slaney L, Maclean I, et al. Antibody to Rmp (outer membrane protein 3) increases susceptibility to gonococcal infection. J Clin Invest. (1993) 91:339-43. doi: 10.1172/jci116190 perhaps, the "triple threat" criteria indicated above that also applies to $2 \mathrm{C} 7$ vaccine: (i) broad representation; (ii) service as a virulence determinant and (iii) a critical role in organism survival.

\section{AUTHOR CONTRIBUTIONS}

SG and JS organized and prepared material for this manuscript. SR and PR contributed in the writing and reviewing of the manuscript.

\section{ACKNOWLEDGMENTS}

This work was supported by grants from the National Institutes of Health/National Institutes of Allergy and Infectious Diseases, AI132296 (to SR and PR), AI114710 (to PR and SG), AI118161 (to SR), AI119327 (to SR and SG), AI114790 (to PR and SR) and AI136007 (to SR and PR).

12. Liu Y, Feinen B, Russell MW. New concepts in immunity to Neisseria gonorrhoeae: innate responses and suppression of adaptive immunity favor the pathogen, not the host. Front Microbiol. (2011) 2:52. doi: $10.3389 /$ fmicb.2011.00052

13. Liu Y, Perez J, Hammer LA, Gallagher HC, De Jesus M, Egilmez NK, et al. Intravaginal administration of interleukin 12 during genital gonococcal infection in mice induces immunity to heterologous strains of Neisseria gonorrhoeae. mSphere. (2018) 3:e00421-17. doi: 10.1128/mSphere.00421-17

14. Liu Y, Egilmez NK, Russell MW. Enhancement of adaptive immunity to Neisseria gonorrhoeae by local intravaginal administration of microencapsulated interleukin 12. J Infect Dis. (2013) 208:1821-9. doi: 10.1093/infdis/jit354

15. Rice PA, Shafer WM, Ram S, Jerse AE. Neisseria gonorrhoeae: drug resistance, mouse models, and vaccine development. Annu Rev Microbiol. (2017) 71:665-86. doi: 10.1146/annurev-micro-090816-093530

16. Plante M, Jerse A, Hamel J, Couture F, Rioux CR, Brodeur BR, et al. Intranasal immunization with gonococcal outer membrane preparations reduces the duration of vaginal colonization of mice by Neisseria gonorrhoeae. J Infect Dis. (2000) 182:848-55. doi: 10.1086/315801

17. Zhu W, Thomas CE, Chen CJ, Van Dam CN, Johnston RE, Davis NL, et al. Comparison of immune responses to gonococcal PorB delivered as outer membrane vesicles, recombinant protein, or Venezuelan equine encephalitis virus replicon particles. Infect Immun. (2005) 73:7558-68. doi: 10.1128/iai.73.11.7558-7568.2005

18. Virji M, Makepeace K, Ferguson DJ, Achtman M, Moxon ER. Meningococcal Opa and Opc proteins: their role in colonization and invasion of human epithelial and endothelial cells. Mol Microbiol. (1993) 10:499-510. doi: 10.1111/j.1365-2958.1993.tb00922.x

19. Drake SL, Koomey M. The product of the pilQ gene is essential for the biogenesis of type IV pili in Neisseria gonorrhoeae. Mol Microbiol. (1995) 18:975-86. doi: 10.1111/j.1365-2958.1995.18050975.x

20. Edwards JL, Brown EJ, Uk-Nham S, Cannon JG, Blake MS, Apicella MA A co-operative interaction between Neisseria gonorrhoeae and complement receptor 3 mediates infection of primary cervical epithelial cells. Cell Microbiol. (2002) 4:571-84. doi: 10.1046/j.1462-5822.2002.t01-1-00215.x

21. de Jonge MI, Hamstra HJ, Jiskoot W, Roholl P, Williams NA, Dankert $\mathrm{J}$, et al. Intranasal immunisation of mice with liposomes containing recombinant meningococcal OpaB and OpaJ proteins. Vaccine. (2004) 22:4021-8. doi: 10.1016/j.vaccine.2004.03.047

22. Moore J, Bailey SE, Benmechernene Z, Tzitzilonis C, Griffiths NJ, Virii $\mathrm{M}$, et al. Recognition of saccharides by the OpcA, OpaD, and OpaB outer membrane proteins from Neisseria meningitidis. J Biol Chem. (2005) 280:31489-97. doi: 10.1074/jbc.M506354200 
23. Cole JG, Jerse AE. Functional characterization of antibodies against Neisseria gonorrhoeae opacity protein loops. PLoS ONE. (2009) 4:e8108. doi: 10.1371/journal.pone.0008108

24. Keiser PB, Gibbs BT, Coster TS, Moran EE, Stoddard MB, Labrie JEIII, et al. A phase 1 study of a group B meningococcal native outer membrane vesicle vaccine made from a strain with deleted lpxL2 and synX and stable expression of opcA. Vaccine. (2010) 28:6970-6. doi: 10.1016/j.vaccine.2010.08.048

25. Callaghan MJ, Lewis S, Sadarangani M, Bailey SE, Chan H, Ferguson DJ, et al. Potential of recombinant opa proteins as vaccine candidates against hyperinvasive meningococci. Infect Immun. (2011) 79:2810-8. doi: 10.1128/iai.01338-10

26. Haghi F, Peerayeh SN, Siadat SD, Zeighami H. Recombinant outer membrane secretin PilQ(406-770) as a vaccine candidate for serogroup B Neisseria meningitidis. Vaccine. (2012) 30:1710-4. doi: 10.1016/j.vaccine.2011.12.076

27. Semchenko EA, Day CJ, Seib KL. MetQ of Neisseria gonorrhoeae is a surface expressed antigen that elicits bactericidal and functional blocking antibodies. Infect Immun. (2017) 85:e00898-16. doi: 10.1128/iai.00898-16

28. Delahay RM, Robertson BD, Balthazar JT, Shafer WM, Ison CA. Involvement of the gonococcal MtrE protein in the resistance of Neisseria gonorrhoeae to toxic hydrophobic agents. Microbiology. (1997) 143:2127-33. doi: 10.1099/00221287-143-7-2127

29. Lee EH, Shafer WM. The farAB-encoded efflux pump mediates resistance of gonococci to long-chained antibacterial fatty acids. Mol Microbiol. (1999) 33:839-45. doi: 10.1046/j.1365-2958.1999.01530.x

30. Ram S, Cullinane M, Blom AM, Gulati S, McQuillen DP, Monks BG, et al. Binding of $\mathrm{C} 4 \mathrm{~b}$-binding protein to porin: a molecular mechanism of serum resistance of Neisseria gonorrhoeae. J Exp Med. (2001) 193:281-95. doi: 10.1084/jem.193.3.281

31. Pettersson A, Kortekaas J, Weynants VE, Voet P, Poolman JT, Bos $\mathrm{MP}$, et al. Vaccine potential of the Neisseria meningitidis lactoferrinbinding proteins LbpA and LbpB. Vaccine. (2006) 24:3545-57. doi: 10.1016/j.vaccine.2006.02.003

32. Price GA, Masri HP, Hollander AM, Russell MW, Cornelissen CN. Gonococcal transferrin binding protein chimeras induce bactericidal and growth inhibitory antibodies in mice. Vaccine. (2007) 25:7247-60. doi: 10.1016/j.vaccine.2007.07.038

33. Stork M, Bos MP, Jongerius I, de Kok N, Schilders I, Weynants VE, et al. An outer membrane receptor of Neisseria meningitidis involved in zinc acquisition with vaccine potential. PLoS Pathog. (2010) 6:e1000969. doi: 10.1371/journal.ppat.1000969

34. Cornelissen CN, Hollander A. TonB-dependent transporters expressed by Neisseria gonorrhoeae. Front Microbiol. (2011) 2:117. doi: 10.3389/fmicb.2011.00117

35. Hobbs MM, Sparling PF, Cohen MS, Shafer WM, Deal CD, Jerse AE. Experimental gonococcal infection in male volunteers: cumulative experience with Neisseria gonorrhoeae strains FA1090 and MS11mkC. Front Microbiol. (2011) 2:123. doi: 10.3389/fmicb.2011.00123

36. Hook EWIII, Olsen DA, Buchanan TM. Analysis of the antigen specificity of the human serum immunoglobulin $\mathrm{G}$ immune response to complicated gonococcal infection. Infect Immun. (1984) 43:706-9.

37. Christodoulides M, McGuinness BT, Heckels JE. Immunization with synthetic peptides containing epitopes of the class 1 outer-membrane protein of Neisseria meningitidis: production of bactericidal antibodies on immunization with a cyclic peptide. J Gen Microbiol. (1993) 139:1729-38. doi: 10.1099/00221287-139-8-1729

38. Jarvis GA. Analysis of C3 deposition and degradation on Neisseria meningitidis and Neisseria gonorrhoeae. Infect Immun. (1994) 62:1755-60.

39. Ram S, McQuillen DP, Gulati S, Elkins C, Pangburn MK, Rice PA. Binding of complement factor $\mathrm{H}$ to loop 5 of porin protein 1A: a molecular mechanism of serum resistance of nonsialylated Neisseria gonorrhoeae. J Exp Med. (1998) 188:671-80. doi: 10.1084/jem.188.4.671

40. Ram S, Sharma AK, Simpson SD, Gulati S, McQuillen DP, Pangburn $\mathrm{MK}$, et al. A novel sialic acid binding site on factor $\mathrm{H}$ mediates serum resistance of sialylated Neisseria gonorrhoeae. J Exp Med. (1998) 187:743-52. doi: $10.1084 /$ jem.187.5.743
41. Li G, Jiao H, Jiang G, Wang J, Zhu L, Xie R, et al. Neisseria gonorrhoeae NspA induces specific bactericidal and opsonic antibodies in mice. Clin Vaccine Immunol. (2011) 18:1817-22. doi: 10.1128/cvi.05245-11

42. Lewis LA, Rice PA, Ram S. The role of gonococcal Neisserial surface protein $\mathrm{A}(\mathrm{NspA})$ in serum resistance and comparison of its factor $\mathrm{H}$ binding properties with that of its meningococcal counterpart. Infect Immun. (2018) 87:e00658-18. doi: 10.1128/IAI.00658-18

43. Zielke RA, Wierzbicki IH, Baarda BI, Gafken PR, Soge OO, Holmes $\mathrm{KK}$, et al. Proteomics-driven antigen discovery for development of vaccines against gonorrhea. Mol Cell Proteomics. (2016) 15:2338-55. doi: 10.1074/mcp.M116.058800

44. Jerse AE, Deal CD. Vaccine research for gonococcal infections: where are we? Sex Transm Infect. (2013) 89 Suppl. 4:iv63-68. doi: 10.1136/sextrans-2013-051225

45. Jerse AE, Bash MC, Russell MW. Vaccines against gonorrhea: current status and future challenges. Vaccine. (2014) 32:1579-87. doi: 10.1016/j.vaccine.2013.08.067

46. Petousis-Harris H, Paynter J, Morgan J, Saxton P, McArdle B, Goodyear-Smith F, et al. Effectiveness of a group B outer membrane vesicle meningococcal vaccine against gonorrhoea in New Zealand: a retrospective case-control study. Lancet. (2017) 390:1603-10. doi: 10.1016/S0140-6736(17)31449-6

47. Semchenko EA, Tan A, Borrow R, Seib KL. The serogroup B meningococcal vaccine Bexsero elicits antibodies to Neisseria gonorrhoeae. Clin Infect Dis. (2018). doi: 10.1093/cid/ciy1061. [Epub ahead of print].

48. Beernink PT, Ispasnie E, Lewis LA, Ram S, Moe GR, Granoff DM. A meningococcal native outer membrane vesicle vaccine with attenuated endotoxin and overexpressed factor $\mathrm{H}$ binding protein elicits gonococcal bactericidal antibodies. J. Infect. Dis. (2018). doi: 10.1093/infdis/yiy609. [Epub ahead of print].

49. Goldblatt D. Conjugate vaccines. Clin Exp Immunol. (2000) 119:1-3. doi: 10.1046/j.1365-2249.2000.01109.x

50. Adderson EE. Antibody repertoires in infants and adults: effects of T-independent and T-dependent immunizations. Springer Semin Immunopathol. (2001) 23:387-403. doi: 10.1007/s281-001-8166-x

51. Grabenstein JD, Klugman KP. A century of pneumococcal vaccination research in humans. Clin Microbiol Infect. (2012) 18 Suppl. 5:15-24. doi: 10.1111/j.1469-0691.2012.03943.x

52. Caesar NM, Myers KA, Fan X. Neisseria meningitidis serogroup B vaccine development. Microb Pathog. (2013) 57:33-40. doi: 10.1016/j.micpath.2013.02.003

53. Zhou D, Stephens DS, Gibson BW, Engstrom JJ, McAllister CF, Lee FK, et al. Lipooligosaccharide biosynthesis in pathogenic Neisseria. Cloning, identification, and characterization of the phosphoglucomutase gene. J Biol Chem. (1994) 269:11162-9.

54. Petricoin EFIII, Danaher RJ, Stein DC. Analysis of the lsi region involved in lipooligosaccharide biosynthesis in Neisseria gonorrhoeae. J Bacteriol. (1991) 173:7896-902. doi: 10.1128/jb.173.24.7896-7902.1991

55. Gibson BW, Melaugh W, Phillips NJ, Apicella MA, Campagnari AA, Griffiss JM. Investigation of the structural heterogeneity of lipooligosaccharides from pathogenic Haemophilus and Neisseria species and of R-type lipopolysaccharides from Salmonella typhimurium by electrospray mass spectrometry. J Bacteriol. (1993) 175:2702-12. doi: 10.1128/jb.175.9.2702-2712.1993

56. Gotschlich EC. Genetic locus for the biosynthesis of the variable portion of Neisseria gonorrhoeae lipooligosaccharide. J Exp Med. (1994) 180:2181-90. doi: 10.1084/jem.180.6.2181

57. Kahler CM, Carlson RW, Rahman MM, Martin LE, Stephens DS. Two glucosyltransferase genes, $\operatorname{lgt} F$ and $r f a K$, constitue the lipooligosaccharide ice (inner core extension) biosynthesis operon of Neisseria meningitidis. J Bacteriol. (1996) 178:6677-84. doi: 10.1128/jb.178.23.6677-6684.1996

58. John CM, Griffiss JM, Apicella MA, Mandrell RE, Gibson BW. The structural basis for pyocin resistance in Neisseria gonorrhoeae lipooligosaccharides. J Biol Chem. (1991) 266:19303-11.

59. Jennings M, Hood D, Peak R, Virji M, Moxon E. Molecular analysis of a locus for the biosynthesis and phase-variable expression of the lacto-N-neotetraose terminal lipopolysaccharide structure 
in Neisseria meningitidis. Mol. Microbiol. (1995) 18:729-40. doi: 10.1111/j.1365-2958.1995.mmi_18040729.x

60. Danaher RJ, Levin JC, Arking D, Burch CL, Sandlin R, Stein DC. Genetic basis of Neisseria gonorrhoeae lipooligosaccharide antigenic variation. $J$ Bacteriol. (1995) 177:7275-9. doi: 10.1128/jb.177.24.7275-7279.1995

61. Yang QL, Gotschlich EC. Variation of gonococcal lipoligosaccharide structure is due to alteration in poly-G tracts in lgt genes encoding glycosyl transferases. J Exp Med. (1996) 183:323-7. doi: 10.1084/jem.183.1.323

62. Banerjee A, Wang R, Uljon SN, Rice PA, Gotschlich EC, Stein DC. Identification of the gene (lgtG) encoding the lipooligosaccharide beta chain synthesizing glucosyl transferase from Neisseria gonorrhoeae. Proc Natl Acad Sci USA. (1998) 95:10872-7. doi: 10.1073/pnas.95. 18.10872

63. Apicella MA, Shero M, Jarvis GA, Griffiss JM, Mandrell RE, Schneider H. Phenotypic variation in epitope expression of the Neisseria gonorrhoeae lipooligosaccharide. Infect Immun. (1987) 55:1755-61.

64. Schneider H, Hammack CA, Apicella MA, Griffiss JM. Instability of expression of lipooligosaccharides and their epitopes in Neisseria gonorrhoeae. Infect Immun. (1988) 56:942-6.

65. Schneider H, Griffiss JM, Boslego JW, Hitchcock PJ, Zahos KM, Apicella MA. Expression of paragloboside-like lipooligosaccharides may be a necessary component of gonococcal pathogenesis in men. J Exp Med. (1991) 174:1601-5. doi: 10.1084/jem.174.6.1601

66. Yamasaki R, Koshino H, Kurono S, Nishinaka Y, McQuillen DP, Kume A, et al. Structural and immunochemical characterization of a Neisseria gonorrhoeae epitope defined by a monoclonal antibody $2 \mathrm{C} 7$; the antibody recognizes a conserved epitope on specific lipo-oligosaccharides in spite of the presence of human carbohydrate epitopes. J Biol Chem. (1999) 51:36550-8. doi: 10.1074/jbc.274.51.36550

67. Apicella MA, Bennett KM, Hermerath CA, Roberts DE. Monoclonal antibody analysis of lipopolysaccharide from Neisseria gonorrhoeae and Neisseria meningitidis. Infect Immun. (1981) 34:751-6.

68. Mandrell R, Schneider H, Apicella M, Zollinger W, Rice PA, Griffiss JM. Antigenic and physical diversity of Neisseria gonorrhoeae lipooligosaccharides. Infect Immun. (1986) 54:63-9.

69. Mandrell RE, Griffiss JM, Macher BA. Lipooligosaccharides (LOS) of Neisseria gonorrhoeae and Neisseria meningitidis have components that are immunochemically similar to precursors of human blood group antigens. Carbohydrate sequence specificity of the mouse monoclonal antibodies that recognize crossreacting antigens on LOS and human erythrocytes. J Exp Med. (1988) 168:107-26. doi: 10.1084/jem.168.1.107

70. Yamasaki R, Bacon BE, Nasholds W, Schneider H, Griffiss JM. Structural determination of oligosaccharides derived from lipooligosaccharide of Neisseria gonorrhoeae F62 by chemical, enzymatic, and two-dimensional NMR methods. Biochemistry. (1991) 30:10566-75. doi: 10.1021/bi00107a028

71. Yamasaki R, Nasholds W, Schneider H, Apicella MA. Epitope expression and partial structural characterization of F62 lipooligosaccharide (LOS) of Neisseria gonorrhoeae: IgM monoclonal antibodies (3F11 and 1-1-M) recognize non-reducing termini of the LOS components. Mol Immunol. (1991) 28:1233-42. doi: 10.1016/0161-5890(91)90010-H

72. Zollinger WD, Mandrell RE. Importance of complement source in bactericidal activity of human antibody and murine monoclonal antibody to meningococcal group B polysaccharide. Infect Immun. (1983) 40:257-64.

73. Schneider H, Hale TL, Zollinger WD, Seid RJr, Hammack CA, Griffiss JM. Heterogeneity of molecular size and antigenic expression within lipooligosaccharides of individual strains of Neisseria gonorrhoeae and Neisseria meningitidis. Infect Immun. (1984) 45:544-9.

74. Schneider H, Griffiss JM, Mandrell RE, Jarvis GA. Elaboration of a 3.6kilodalton lipooligosaccharide, antibody against which is absent from human sera, is associated with serum resistance of Neisseria gonorrhoeae. Infect Immun. (1985) 50:672-7.

75. O'Connor ET, Swanson KV, Cheng H, Fluss K, Griffiss JM, Stein DC. Structural requirements for monoclonal antibody 2-1-L8 recognition of neisserial lipooligosaccharides. Hybridoma (Larchmt). (2008) 27:71-9. doi: 10.1089/hyb.2007.0552

76. Muhlecker W, Gulati S, McQuillen DP, Ram S, Rice PA, Reinhold VN. An essential saccharide binding domain for the $\mathrm{mAb} 2 \mathrm{C} 7$ established for
Neisseria gonorrhoeae LOS by ES-MS and MSn. Glycobiology. (1999) 9:15771. doi: $10.1093 / \mathrm{glycob} / 9.2 .157$

77. Lam J. Genetic Adaptation Contributing to Increased Gonococcal Fitness during Vaginal Infection of CEACAM-Humanized Mice. Master's thesis, Toronto, ON: University of Toronto (2017).

78. Ram S, Gulati S, Lewis LA, Chakraborti S, Zheng B, DeOliveira RB, et al. A novel sialylation site on Neisseria gonorrhoeae lipooligosaccharide links heptose II lactose expression with pathogenicity. Infect Immun. (2018) 86:e0285-18. doi: 10.1128/IAI.00285-18

79. Elkins C, Carbonetti NH, Varela VA, Stirewalt D, Klapper DG, Sparling $\mathrm{PF}$. Antibodies to $\mathrm{N}$-terminal peptides of gonococcal porin are bactericidal when gonococcal lipopolysaccharide is not sialylated. Mol Microbiol. (1992) 6:2617-28. doi: 10.1111/j.1365-2958.1992.tb01439.x

80. Gulati S, Mu X, Zheng B, Reed GW, Ram S, Rice PA. Antibody to reduction modifiable protein increases the bacterial burden and the duration of gonococcal infection in a mouse model. J Infect Dis. (2015) 212:311-5. doi: 10.1093/infdis/jiv024

81. Devyatyarova-Johnson M, Rees IH, Robertson BD, Turner MW, Klein NJ, Jack DL. The lipopolysaccharide structures of Salmonella enterica serovar Typhimurium and Neisseria gonorrhoeae determine the attachment of human mannose-binding lectin to intact organisms. Infect Immun. (2000) 68:3894-9. doi: 10.1128/IAI.68.7.3894-3899. 2000

82. Gulati S, Sastry K, Jensenius JC, Rice PA, Ram S. Regulation of the Mannan-binding lectin pathway of complement on Neisseria gonorrhoeae by C1-inhibitor and alpha(2)-macroglobulin. J Immunol. (2002) 168:4078-86. doi: 10.4049/jimmunol.168.8.4078

83. Estabrook MM, Jack DL, Klein NJ, Jarvis GA. Mannose-binding lectin binds to two major outer membrane proteins, opacity protein and porin of Neisseria meningitidis. J Immunol. (2004) 172:3784-92. doi: 10.4049/jimmunol.172.6.3784

84. Gulati S, Cox A, Lewis LA, Michael FS, Li J, Boden R, et al. Enhanced factor $\mathrm{H}$ binding to sialylated Gonococci is restricted to the sialylated lacto-N-neotetraose lipooligosaccharide species: implications for serum resistance and evidence for a bifunctional lipooligosaccharide sialyltransferase in Gonococci. Infect Immun. (2005) 73:7390-7. doi: 10.1128/IAI.73.11.7390-7397.2005

85. Madico G, Ngampasutadol J, Gulati S, Vogel U, Rice PA, Ram S. Factor H binding and function in sialylated pathogenic neisseriae is influenced by gonococcal, but not meningococcal, porin. J Immunol. (2007) 178:4489-97. doi: 10.4049/jimmunol.178.7.4489

86. Ngampasutadol J, Ram S, Gulati S, Agarwal S, Li C, Visintin A, et al. Human factor $\mathrm{H}$ interacts selectively with Neisseria gonorrhoeae and results in species-specific complement evasion. J Immunol. (2008) 180:3426-35. doi: $10.4049 /$ jimmunol.180.5.3426

87. Kim JJ, Zhou D, Mandrell RE, Griffiss JM. Effect of exogenous sialylation of the lipooligosaccharide of Neisseria gonorrhoeae on opsonophagocytosis. Infect Immun. (1992) 60:4439-42.

88. Rest RF, Frangipane JV. Growth of Neisseria gonorrhoeae in CMP$\mathrm{N}$-acetylneuraminic acid inhibits nonopsonic (opacity-associated outer membrane protein-mediated) interactions with human neutrophils. Infect Immun. (1992) 60:989-97.

89. Gill MJ, McQuillen DP, van Putten JP, Wetzler LM, Bramley J, Crooke H, et al. Functional characterization of a sialyltransferase-deficient mutant of Neisseria gonorrhoeae. Infect Immun. (1996) 64:3374-8.

90. van Putten JP. Phase variation of lipooligosaccharide directs interconversion of invasive and immuno-resistant phenotypes of Neisseria gonorrhoeae. EMBO J. (1993) 12:4043-51. doi: 10.1002/j.1460-2075. 1993.tb06088.x

91. Rest RF. Association of bacteria with human phagocytes. Methods Enzymol. (1995) 253:12-26. doi: 10.1016/S0076-6879(95)53004-5

92. Smith NH, Maynard Smith J, Spratt BG. Sequence evolution of the porB gene of Neisseria gonorrhoeae and Neisseria meningitidis: evidence of positive Darwinian selection. Mol Biol Evol. (1995) 12:363-70.

93. Apicella MA, Mandrell RE, Shero M, Wilson M, Griffiss JM, Brooks GF, et al. Modification by sialic acid of Neisseria gonorrhoeae lipooligosaccharide epitope expression in human urethral exudates: an 
immunoelectron microscopic analysis. J Infect Dis. (1990) 162:506-12. doi: 10.1093/infdis/162.2.506

94. Schneider H, Cross AS, Kuschner RA, Taylor DN, Sadoff JC, Boslego JW, et al. Experimental human gonococcal urethritis: 250 Neisseria gonorrhoeae MS11 mkC are effective. J Infect Dis. (1995) 172:180-5. doi: 10.1093/infdis/172.1.180

95. Landig CS, Hazel A, Kellman BP, Fong JJ, Schwarz F, Agarwal S, et al. Evolution of the exclusively human pathogen Neisseria gonorrhoeae: human-specific engagement of immunoregulatory Siglecs. Evol Appl. (2019) 2019:337-49. doi: 10.1111/eva.12744

96. Chakraborti S, Lewis LA, Cox AD, St Michael F, Li J, Rice PA, et al. Phase-variable heptose I glycan extensions modulate efficacy of 2C7 vaccine antibody directed against Neisseria gonorrhoeae lipooligosaccharide. J Immunol. (2016) 196:4576-86. doi: 10.4049/ jimmunol.1600374

97. McLaughlin SE, Cheng H, Ghanem KG, Yang Z, Melendez J, Zenilman J, et al. Urethral exudates of men with Neisseria gonorrhoeae infections select a restricted lipooligosaccharide phenotype during transmission. J Infect Dis. (2012) 206:1227-32. doi: 10.1093/infdis/jis481

98. Ngampasutadol J, Rice PA, Walsh MT, Gulati S. Characterization of a peptide vaccine candidate mimicking an oligosaccharide epitope of Neisseria gonorrhoeae and resultant immune responses and function. Vaccine. (2006) 24:157-70. doi: 10.1016/j.vaccine.2005.07.065
99. Boslego JW, Tramont EC, Chung RC, McChesney DG, Ciak J, Sadoff JC, et al. Efficacy trial of a parenteral gonococcal pilus vaccine in men. Vaccine. (1991) 9:154-62. doi: 10.1016/0264-410X(91)90147-X

100. Cohen MS, Cannon JG. Human experimentation with Neisseria gonorrhoeae: progress and goals. J Infect Dis. (1999) 179:S375-9. doi: 10. 1086/513847

101. Rice PA, McQuillen DP, Gulati S, Jani DB, Wetzler LM, Blake MS, et al. Serum resistance of Neisseria gonorrhoeae. Does it thwart the inflammatory response and facilitate the transmission of infection? Ann N Y Acad Sci. (1994) 730:7-14. doi: 10.1111/j.1749-6632.1994. tb44234.x

Conflict of Interest Statement: The authors declare that the research was conducted in the absence of any commercial or financial relationships that could be construed as a potential conflict of interest.

Copyright $\odot 2019$ Gulati, Shaughnessy, Ram and Rice. This is an open-access article distributed under the terms of the Creative Commons Attribution License (CC BY).

The use, distribution or reproduction in other forums is permitted, provided the original author(s) and the copyright owner(s) are credited and that the original publication in this journal is cited, in accordance with accepted academic practice. No use, distribution or reproduction is permitted which does not comply with these terms. 